\title{
A decimal code for the developmental stages of maize and its relation to accumulated heat units
}

\section{J. J. R. Groot, M. J. Kropff, F. J. H. Vossen, C. J. T. Spitters ${ }^{1}$ and R. Rabbinge}

Department of Theoretical Production Ecology, Agricultural University, P.O. Box 430, 6700 AK Wageningen, Netherlands

Received 26 April 1985; accepted 24 September 1985

Key words: maize, growth stage, phenological scale, temperature

\begin{abstract}
A detailed phenological scale for maize has been developed for use under West European conditions. Primary and secondary growth stages have been distinguished and characterized with a decimal code. Growth stages are easy recognizable in the field.

Development codes have been related to an ontogenetic time expressed in accumulated temperature by using detailed phenological observations from two field experiments. An approximately linear relationship was found between accumulated temperature and development codes with a discontinuity around anthesis.
\end{abstract}

\section{Introduction}

Many plant characteristics and processes depend upon the developmental stage of the plant. Therefore, a clear description of the different stages is required, acceptable for plant physiologists, plant breeders, crop protectionists, and crop growth modellers in particular. Besides for scientific use, the code should also be appropriate for field use by maize growers since decisions about husbandry practices are often related to the developmental stage of the crop.

Aim of the research was to arrive at a detailed stage description and a decimal code for the phenology of maize for use under West European conditions. A combination was made of the developmental stage description given by Hanway (as described by Bottrell, 1979) and the stage description given by Schütte \& Meier (1981). In addition, field observations were done to improve and to test the stage description.

Accumulated temperature has proven to be more suitable than calendar time to describe the phenology of maize (Becker et al., 1953; Becker, 1974; Brown, 1969;

${ }^{1}$ Present address: Foundation of Agricultural Plant Breeding (SVP), P.O. Box 117, 6700 AC Wageningen, Netherlands. 
Bloc \& Gouet, 1976, 1979). The second aim of the research was, therefore, to relate the developmental codes to an ontogenetic time expressed in accumulated temperature rather than to calendar days.

\section{Phenological scale}

\section{General principles}

In developing the phenological scale some of the criteria modified after Zadoks et al. (1974) have been used.

- The growth stages must be easily recognizable under field circumstances without specialized equipment.

- The scale should embrass the complete life cycle: the first stage is the start of germination, the last stage is the end of innate seed dormancy.

- To simplify data processing, the primary stages should be identified with the digits 0 to 9 .

- In order to provide more detail, each primary stage should be subdivided into an equal number of secondary growth stages.

We add to this:

- Codes should be equidistant on an ontogenetic time scale (in general accumulated heat units).

The best known and most widely used scale for the development of maize was designed by Hanway (1966). The growth stages are based upon observations of hybrid maize in the Midwest USA. The growth stages described by Hanway are easily recognizable in the field, but for use in West European conditions modification of the stage description is necessary. The need for modification is caused by differences in environmental conditions, and the use of different maize varieties, which result in differences in leaf number, and the length of time between different developmental stages (e.g. Bottrell, 1979; Brown, 1976; Duncan et al., 1973; Larson \& Hanway, 1976). Moreover, Hanway uses only 10 stages. In order to obtain more accuracy, it is necessary to distinguish more stages. Schütte \& Meier (1981) designed a code for the growth stages of maize for the Federal Republic of Germany. The disadvantage of this scale is the fact that several developmental stages can be referred to with different codes, instead of one code for each developmental stage.

Both the Hanway scale and the scale by Schütte \& Meier do not meet the mentioned criteria, so a new scale has been developed.

Table 1. A decimal code for the developmental stages of maize. Primary stages and secondary stages. Stages of Hanway and Schütte \& Meier are given as far as stages are comparable.

Hanway (1966) Schütte \& Meier (1981)

\section{Germination}

0.00 dry seed

01

0.25 imbibition of the seed

03

0.50 radicle emerged from the seed

05

0.75 Coleoptile emerged from the seed

07 
Table 1 (continued)

Hanway (1966) Schütte \& Meier (1981)

1 Emergence and seedling growth

1.00 Coleoptile emerging from the soil $\quad 0 \quad 11$

1.25 first leaf unfolded

17

1.502 leaves unfolded

$0.5 \quad 19$

1.753 leaves unfolded

11
17
19
21

2 Stem elongation (1)

2.004 leaves unfolded

2.255 leaves unfolded

2.506 leaves unfolded

2.757 leaves unfolded

23

3 Stem elongation (2)

3.008 leaves unfolded

3.259 leaves unfolded

3.5010 leaves unfolded

3.7511 leaves unfolded

$1.5 \quad 24$

4 Stem elongation (3)

4.0012 leaves unfolded

4.2513 leaves unfolded

4.5014 leaves unfolded

4.7515 or more leaves unfolded

22

23

25

$2 \quad 26$

26

$2.5-26$

26

$27,53,71$

59,73

3.5

$\pm 5 \quad 61$

65,75

67

77

81

$\pm 6$

82

7.00 early milk ripe, silks completely dry

7.25 first dents become visible

7.50 half milk ripe, milk line halfway kernel

7.75 late milk ripe

\section{Dry ripe}

8.00 early dry ripe, physiological maturity, silage-harvest

$8.25-$

8.50 medium dry

8.75 late dry

\section{Ripeness}

9.00 hard ripe

$9.25-$

$9.50-$

9.75 end of seed dormancy
85 


\section{J. J. R. GROOT ET AL.}

\section{Primary stages}

Table 1 shows the growth stages of maize. The primary stages are coded with the digits $0-9$. Developmental stage (DC) 0 represents the period of germination of the seed in the soil, stage 1 represents the coleoptile emergence from the soil and the seedling growth. The period of stem elongation is subdivided into 3 primary stages.

Stage 2 - stem elongation (1): during this stage the internodes below the fifth, sixth and seventh leaves have begun to elongate.

Stage 3 - stem elongation (2): during this period the stem is elongating rapidly, the internodes below the fifth and sixth leaves are fully elongated.

Stage 4 - stem elongation (3): the stem is still elongating, but the most characteristic features are the emergence of the tassel from the whorl and the rapid increase in size of the ear.

Stage 5 represents the period of flowering.

The caryopsis development is divided into four stages: stage 6 - water ripe; stage

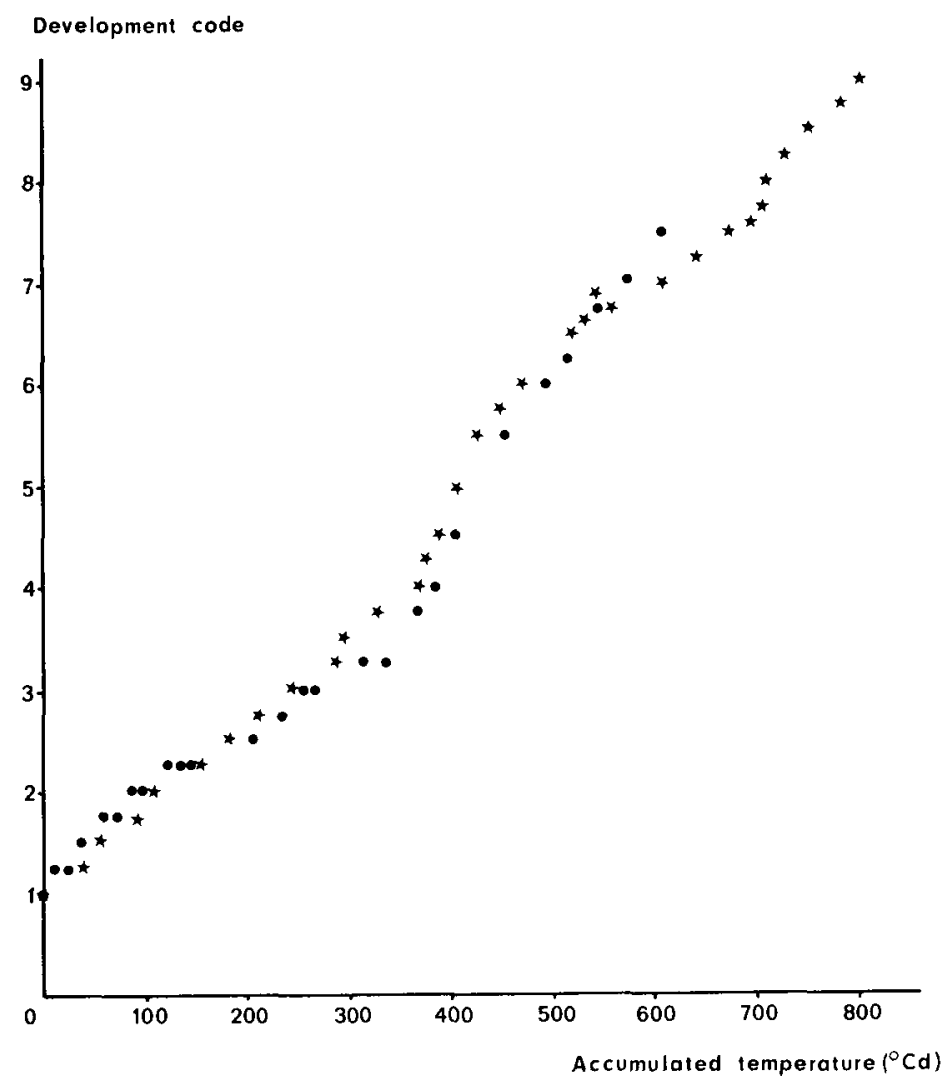

Fig. 1. Relationship between developmental codes and accumulated temperatures as observed for maize cv. LG11 in the years 1982 (x) and 1983 (o). Daily average air temperatures were accumulated with a base temperature of $10^{\circ} \mathrm{C}$. 
7 - milk ripe; stage 8 - dry ripe, and stage 9 - ripeness. During the water ripe stage, the whole kernel content is still in the liquid phase. During the milk ripe stage there is a milk-to-solid conversion of the endosperm. The liquid content of the kernel has a milky structure during this stage. At the dry ripe stage, kernel milk is no longer present, and the kernels have reached physiological maturity. Kernels will continue to loose moisture until stage 9 , ripeness, is reached. The term dough ripe, which is common in the description of developmental stages in cereals (Feekes, 1941; Zadoks et al., 1974) and which is also used in stage description of maize (Hanway, 1966; Schütte \& Meier, 1981) is not used in the stage description. During the kernel solidification, the milk disappears gradually and solid kernel material is formed. The doughly structure found in caryopsis development of most cereals does not occur during maize development. At the end of stage 9, physiological maturity is reached.

\section{Secondary stages}

Each primary growth stage is subdivided into four secondary growth stages to obtain a more detailed description (Table 1). Secondary stages before silking are mainly classified to the number of fully emerged leaves (leaves with the collar visible). When during stage 4 the final number of leaves that have been unfolded is 15 or less and the tassel has been fully emerged, stages are continued at stage 5.00. Growth stages after silking are identified by the development of the kernels on the ear. Some extra attention should be paid to stages used in estimating maturity. After the first dents have become visible during the milk ripe stage, the half milk ripe stage is reached. This stage is easily recognizable by breaking an ear in half and inspecting the smooth endosperm side on the top half of the ear. On this side of the kernels a line can be seen, which marks the boundary between the solid and liquid phase of the endosperm. When this line is positioned halfway down the kernel, the stage is half milk ripe. This stage is considered to be useful in predicting harvest time (Crookston et al., 1982).

Stage 8, physiological maturity, is often found to coincide with black layer formation in the placental region of the kernels (Daynard \& Duncan, 1969; Daynard, 1972). However, the black layer is not always detectable (Crookston et al., 1982). Therefore it is important to look for both the black layer and milk line appearance in estimating physiological maturity. For information about the moisture content of the kernels at the different developmental stages we refer to Crookston et al. (1982).

\section{Development and accumulated temperature}

It is generally agreed that developmental rate of maize is a function of temperature and that periods between stages of development are better characterized by accumulated temperature than by number of calendar days (Bunting, 1976; Cross \& Zuber, 1972; Bloc \& Gouet, 1979).

Several methods of defining effective temperature for maize development have been proposed in the literature. The methods differ in their assumptions about the 
relation between developmental rate and daily maximum and minimum temperature and in their assumptions about the base temperature for development. However, the methods hardly differ in ability to predict the duration of the major developmental periods (from seedling emergence to flowering and from flowering to ripe grain) (e.g. Cross \& Zuber, 1972; Bloc \& Gouet, 1979; Bunting, 1976). Therefore, the simplest and most wide-spread method of defining effective daily temperature was applied.

In this method a base temperature is subtracted from the daily mean, and negative values are discarded (Bunting, 1976). The calculation of accumulated temperature starts at plant emergence.

$$
T_{\text {eff }}=\left(T_{\min }+T_{\text {max }}\right) / 2-T_{\mathrm{b}} \quad T_{\text {eff }} \geqslant 0
$$

where $T_{\text {eff }}$ represents effective daily temperature, $T_{\min }$ is daily minimum temperature, $T_{\max }$ is daily maximum temperature and $T_{\mathrm{b}}$ is the base temperature. As base temperature $10^{\circ} \mathrm{C}$ is used. Air temperatures measured at $1.50 \mathrm{~m}$ height were used.

This method was checked for Dutch conditions with a data set supplied by $O$. Dolstra (Foundation for Agricultural Plant Breeding (SVP), Wageningen).

Maize cv. LG11 was sown at an early and a normal time in each of six successive years at the same site and dates of seedling emergence and silking were recorded. Over sowing times and over years the coefficient of variation $(\mathrm{CV}=\sigma / \mu)$ for the period from emergence to $50 \%$ silking was $35 / 375 \approx 0.09$ when measured in accumulated temperature and $9.7 / 75 \approx 0.13$ when measured in calendar days. For seven other field experiments with maize cv. LG11 (data from Struik, 1983; Struik \& Deinum, 1982; and own observations), the advantage of accumulated temperatures over calendar days was greater: $\mathrm{CV}$ was $10.9 / 417 \approx 0.026$ for accumulated temperatures and $10.6 / 70 \approx 0.15$ for calendar days. In these latter experiments, the period from seedling emergence to anthesis (DC5) was considered and five years were represented. Dates of emergence varied greatly among experiments.

Development of maize cv. LG11 was followed in time in terms of the scale presented in Table 1 in field experiments carried out in Wageningen in 1982 and 1983. All stages described were easily recognizable in the field. Fig. 1 defines in a broad way how the presented developmental codes are related to the ontogenetic age, expressed in accumulated temperatures.

\section{Conclusions and discussion}

The phenological scale for the developmental stages for maize has been used successfully in the field. All stages described were easily recognizable.

In describing the progression in development, there is an advantage of using accumulated temperature over calendar days. A substantial part of the variation in developmental rate may, however, still remain unexplained. Development proceeded very synchronously in the 2 years. The relation between developmental code and accumulated temperature can be partitioned into an approximately linear relation for the period from seedling emergence (DC1) to the last stage of stem 
elongation (DC4) and approximately linear relation for the period from water ripe (DC6) to hard ripe (DC9) with a discontinuity around flowering (DC5) (Fig. 1).

\section{Acknowledgements}

The authors are indebted to $\mathrm{Mr} \mathrm{O}$. Dolstra for kindly offering data on maize development over six years.

\section{References}

Becker, W. R., 1974. Warmtesommen voor de maisteelt als basis voor een zone-indeling van Nederland. Landbouwkundig Tijdschrift 86: 5.

Becker, W. R., F. J. Dijkhuis \& C. Kan, 1953. De bepaling van de specifieke warmtebehoefte van mais. Jaarverslag CILO (1953), Wageningen.

Bloc, D. \& J. P. Gouet, 1976. Influence of accumulated heat units on the maturity of corn. In: Agrometeorology of the maize (corn) crop. World Meteorological Organization Report 481:76-83.

Bloc, D. \& J. P. Gouet, 1979. Influence des sommes de températures sur la date de floraison femelle et la maturité du mais. Association Génerale des Producteurs de Mais, Institut Technique des Céréales et Fourrages, France.

Bottrell, D.G., 1979. Guidelines for integrated control of maize pests. FAO Plant Production and Protection Paper 18: 1-91.

Brown, D.M., 1969. Heat units for corn in Southern Ontario. Factsheet AGDEX 111/31. Information Leaflet, Ministry of Agriculture and Food, Toronto, Ontario, $4 \mathrm{pp}$.

Brown, D. M., 1976. Response of maize to environmental temperatures: A review. In: Agrometeorology of the maize (corn) crop. World Meteorological Organization Report 481: 15-26.

Bunting, E.S., 1976. Accumulated temperature and maize development in England. Journal of Agricultural Science, Cambridge 87: 577-583.

Crookston, R. K., J. J. Afuakwa \& J. Jones, 1982. Visual maturity indicators for corn - kernel milk line more useful than black layer. Proceedings 37th Annual Corn \& Sorghum Conference (Chicago, Illinois) ASTA Publication 37: 176-187.

Cross, H. Z. \& M. S. Zuber, 1972. Prediction of flowering dates in maize based on different methods of estimating thermal units. Agronomy Journal 64: 351-355.

Daynard, T. B., 1972. Relationships among black layer formation, grain moisture percentage, and heat unit accumulation in corn. Agronomy Journal 64: 716-719.

Daynard, T. B. \& W. G. Duncan, 1969. The black layer and grain maturity in corn. Crop Science 9: 473476.

Duncan, W. G., D. R. Davies \& W. H. Chapman, 1973. Developmental temperatures in corn. Proceedings Soil and Crop Science Society of Florida 32: 59-63..

Feekes, E., 1941. De tarwe en haar milieu. Verslagen Technische Tarwe Commissie 12: 523-888.

Hanway, J. J., 1966. How a corn plant develops. Special report No 98, Iowa State University Press, Ames, Iowa, $18 \mathrm{pp}$.

Larson, W. E. \& J. J. Hanway, 1976. Corn production. In: G. F. Sprague (Ed.), Corn and corn improvement. American Society of Agronomy, Madison, Special Publication 18: 625-669.

Schütte, F., \& U. Meier, 1981. Entwicklungsstadien des Mais, Biol. Bundesanstalt für Land- und Forstwirtschaft, Braunschweig. Merkblatt 27/4, 10 pp.

Struik, P. C., 1983. The effects of switches in photoperiod on crop morphology, production and quality of forage maize under field conditions. Mededelingen Landbouwhogeschool Wageningen 83 (2): 101124.

Struik, P. C. \& B. Deinum, 1982. Effect of light intensity after flowering on the productivity and quality of silage maize. Netherlands Journal of Agricultural Science 30: 297-316.

Zadoks, J. C., T. T. Chang \& C. F. Konzak, 1974. A decimal code for the growth stages of cereals. Weed Research 14: 415-421. 